\title{
Activation and Desensitization of Hippocampal Kainate Receptors
}

\author{
Timothy J. Wilding and James E. Huettner \\ Department of Cell Biology and Physiology, Washington University School of Medicine, St. Louis, Missouri 63110
}

We have used whole-cell recordings and rapid agonist applications to characterize the physiological properties of kainate receptors expressed by rat hippocampal neurons in dissociated cell culture. Activation of NMDA and AMPA receptors was prevented by inclusion of the noncompetitive antagonists MK$801(2 \mu \mathrm{M})$ and GYKI $53655(100 \mu \mathrm{M})$, respectively. In the presence of these inhibitors, both kainate $\left(E_{50}=23 \mu \mathrm{M}\right)$ and glutamate $\left(E C_{50}=310 \mu \mathrm{M}\right)$ evoked desensitizing currents. Maximal peak currents for kainate with GYKI 53655 were $15 \pm$ $3 \%$ as large as in control solutions without GYKI. In contrast to currents mediated by AMPA receptors, kainate currents recorded in GYKI were blocked potently by lanthanum $\left(\mathrm{IC}_{50}=2\right.$ $\mu \mathrm{M})$ and were desensitized by $1 \mu \mathrm{M} 2 S, 4 R$-4-methylglutamate (SYM 2081). Coapplication of either $5 \mu \mathrm{M}$ AMPA or $500 \mu \mathrm{M}$ aspartate had little effect on responses to kainate, although AMPA alone elicited current at $1 \mathrm{~mm}$. In most cells, the currents evoked by kainate, glutamate, and SYM 2081 varied linearly with membrane potential and reversed near $0 \mathrm{mV}$. Kainate elicited substantial current at steady state ( $\sim 30 \%$ of peak), whereas responses to glutamate and SYM 2081 desensitized almost completely within $0.2-2 \mathrm{sec}$. Inhibition produced by a 10 sec desensitizing prepulse was half-maximal at $0.22 \mu \mathrm{M}$ for SYM 2081 and $13 \mu \mathrm{M}$ for glutamate. Recovery from desensitization to kainate and glutamate was $>80 \%$ complete within 60 sec but was three- to fourfold slower after exposure to SYM 2081. Exposure to Concanavalin A blocked desensitization of the currents but also reduced the peak current amplitudes. Collectively, these results confirm that kainate-preferring receptors underlie the currents evoked by kainate, glutamate, or SYM-2081 in the presence of GYKI 53655; they are not mediated by electrogenic transport or by AMPA-preferring receptors that are insensitive to GYKI. In contrast to previous work on embryonic hippocampal neurons, our results show that the properties of kainate receptors expressed by cells from older animals are distinct from those displayed by homomeric assemblies of the GluR6 subunit.

Key words: AMPA receptors; lanthanum; SYM 2081; GYKI 53655; glutamate; Concanavalin A
Neurons in the brain and spinal cord express several different glutamate receptor subtypes, including at least three distinct receptors that directly gate ion channels. These three subtypes have been named for the agonists NMDA, AMPA, and kainate (Watkins and Evans, 1981; Hollmann and Heinemann, 1994). Both NMDA and AMPA receptors have been studied extensively, and the roles that they play in synaptic transmission are fairly well established. In contrast, much less is known about the properties of kainate receptors, and very little has been determined concerning their function in the nervous system.

Analysis of cloned receptor subunits expressed in Xenopus laevis oocytes or mammalian cell lines suggests that AMPA receptors are composed of subunits GluR1 through GluR4 (Boulter et al., 1990; Keinänen et al., 1990), whereas GluR5 through GluR7 and the KA1 and KA2 subunits contribute to kainate receptors (Bettler et al., 1990, 1992; Egebjerg et al., 1991; Sommer et al., 1992). GluR5 and GluR6 can form functional homomeric channels (Bettler et al., 1990; Egebjerg et al., 1991; Sommer et al., 1992). The other kainate receptor subunits apparently do not form homomeric ion channels but, instead, can contribute to heteromeric assemblies with GluR5 and GluR6 (Herb et al., 1992;

\footnotetext{
Received Dec. 19, 1996; revised Jan. 30, 1997; accepted Feb. 4, 1997.

This work was supported by National Institutes of Health (NS30888) and by the McDonnell Center for Cellular and Molecular Neurobiology. We are grateful to Ken Jones and David Hesson of Symphony Pharmaceuticals, Malvern, PA, for providing SYM 2081, to David Leander of Eli Lilly and Company, Indianapolis, IN, for providing GYKI 53655, and to Mike Finley and Chris Lee for critical reading of this manuscript Correspondence should be addressed to Dr. James E. Huettner, Washington University School of Medicine, Department of Cell Biology and Physiology, 660 South Euclid Avenue, St. Louis, MO 63110.

Copyright (C) 1997 Society for Neuroscience 0270-6474/97/172713-09\$05.00/0
}

Lomeli et al., 1992; Sakimura et al., 1992). The anatomical distribution of kainate receptor subunits has been studied by in situ hybridization (Wisden and Seeburg, 1993; Bahn et al., 1994) and immunocytochemistry (Huntley et al., 1993; Petralia et al., 1994). In hippocampus, mRNAs for all five subunits are expressed throughout development in the majority of cell types (Bahn et al., 1994); however, physiological detection of kainate receptormediated currents in hippocampal neurons has proven difficult (Patneau et al., 1993; Spruston et al., 1995).

Recent work from Lerma's group has demonstrated the expression of functional kainate receptors by embryonic hippocampal neurons in culture (Lerma et al., 1993; Paternain et al., 1995). In the majority of cells that they studied, the physiological properties of currents mediated by kainate receptors were very similar to those displayed by homomeric GluR6 receptors. Analysis of subunit expression by single-cell PCR confirmed that most of the cells expressed mRNA for GluR6 and that a few cells expressed GluR5, but mRNAs for the GluR7, KA1, and KA2 subunits were not detected (Ruano et al., 1995).

In the present study, we have used the selective AMPA receptor antagonist GYKI 53655 (Paternain et al., 1995; Wilding and Huettner, 1995) to isolate currents mediated by kainate receptors in cultured hippocampal neurons from 2- to 5-d-old rats. In contrast to the properties observed for homomeric GluR6 receptors, currents mediated by kainate receptors in postnatal hippocampal neurons show incomplete desensitization to kainate and a reduction in peak amplitude after exposure to Concanavalin A.

A preliminary report of these results has appeared (Wilding and Huettner, 1996). 


\section{MATERIALS AND METHODS}

Cell culture. Primary cultures of hippocampal neurons were prepared from 2- to 5-d-old Long Evans rats. Hippocampi from two rat pups were cut into $500 \mu \mathrm{m}$ slices with a McIlwane tissue chopper. Subiculum and entorhinal cortex were removed from each slice with fine forceps, and the slices were transferred to a vial containing a micro stir bar. The tissue was incubated with gentle stirring at $30-35^{\circ} \mathrm{C}$ in Earle's balanced salt solution (EBSS) containing papain $(20 \mathrm{U} / \mathrm{ml}$; Worthington Biochemical, Freehold, NJ). After 90 min, the tissue was rinsed with EBSS containing BSA and ovomucoid at $1 \mathrm{mg} / \mathrm{ml}$. Cells were dissociated by trituration with a fire-polished Pasteur pipette and then plated onto glass coverslips coated with poly-DL-ornithine or matrigel (Becton Dickinson, Mountain View, $\mathrm{CA}$ ). In some cases the freshly dissociated neurons were plated onto a preestablished layer of cortical astrocytes. Cultures were maintained at $37^{\circ} \mathrm{C}$ in Eagle's MEM with $20 \mathrm{~mm}$ glucose, $0.5 \mathrm{~mm}$ glutamine, $100 \mathrm{U} / \mathrm{ml}$ penicillin, $0.1 \mathrm{mg} / \mathrm{ml}$ streptomycin, and $5 \%$ rat serum. Most recordings were obtained from cells that had been in culture for 7-21 d; however, a few experiments were performed at earlier or later times in vitro. Current amplitude increased with time in culture, but no other systematic variations were observed.

Electrophysiology. Culture dishes were perfused at a rate of $1-2 \mathrm{ml} / \mathrm{min}$ with Tyrode's solution, which contained (in $\mathrm{mm}$ ) $150 \mathrm{NaCl}, 4 \mathrm{KCl}, 2$ $\mathrm{MgCl}_{2}, 2 \mathrm{CaCl}_{2}, 10$ glucose, and $10 \mathrm{HEPES}$, pH-adjusted to 7.4 with $\mathrm{NaOH}$. Recording pipettes were pulled from Boralex glass and filled with an internal solution composed of (in mM) 10 EGTA, $5 \mathrm{CsCl}$, and 10 HEPES, pH-adjusted to 7.4 with $\mathrm{CsOH}$ and either $140 \mathrm{~mm} \mathrm{CsF}$ or $\mathrm{CsCH}_{3} \mathrm{SO}_{3}$. The open tip resistance of whole-cell pipettes was 1-5 $\mathrm{M} \Omega$. An agar bridge prepared in $4 \mathrm{M} \mathrm{KCl}$ connected the bath to a ground well, filled with internal solution, that contained the reference electrode. Whole-cell currents were recorded with an Axopatch 200A amplifier (Axon Instruments, Foster City, CA), filtered at $1 \mathrm{kHz}(-3 \mathrm{~dB}, 4$-pole Bessel), and digitized at $5-10 \mathrm{kHz}$. Membrane potentials have been corrected for a junction potential of $-10 \mathrm{mV}$ between the Tyrode's solution, in which seals were formed, and the internal solution.

Drug applications. Control or agonist-containing solutions were applied to cells by local perfusion from a multibarreled pipette. One end of a 250 $\mu l$ microcap $[1.58 \mathrm{~mm}$ inner diameter (i.d.); Drummond Scientific, Broomall, PA] was fire-polished to yield an opening of $\sim 400-500 \mu \mathrm{m}$. Eight fused silica tubes ( $320 \mu \mathrm{m}$ i.d.; J \& W Scientific, Folsom, CA) were aligned within the microcap to yield a dead volume of much less than 1 $\mu$ l. For rapid applications, the drug reservoirs were held under static air pressure (10-15 psi), and solution flow to the delivery tubes was controlled by computer-gated electronic valves (General Valve or The Lee Company). The speed of extracellular solution exchange was determined by monitoring the holding current while switching from control to a high potassium test solution $(10 \mathrm{~mm} \mathrm{KCl})$. In the whole-cell recording mode exposure to the test solution developed along an approximately exponential time course with a time constant of 5-15 msec. Solution exchange at the open tip of a patch electrode was complete in $0.5-1$ msec.

Because $\mathrm{EC}_{50}$ and $\mathrm{IC}_{50}$ are expected to exhibit log-normal distributions (see Hancock et al., 1988), concentration-response relations were fit by nonlinear regression (Sigma Plot, Jandel Scientific, San Rafael, CA) with a form of the logistic equation (De Lean et al., 1978) that is designed to yield logarithmic error estimates (Woodward et al., 1995). For receptor activation the normalized peak current was fit with: $I / I$ max $=1 /(1+$ $\left(10^{-p E C_{50}} /[\text { agonist] })^{n}\right)$, in which $\mathrm{EC}_{50}$ is the concentration that produced half-maximal activation $\left(p E C_{50}=-\log \mathrm{EC}_{50}\right)$ and $n$ is the slope factor. For steady-state inhibition the normalized peak current was fit with: $I / I$ control $=1 /\left(1+\left([\text { antagonist }] / 10^{-\mathrm{pIC}^{2} 0}\right)^{n}\right)$, in which $\mathrm{IC}_{50}$ is the concentration that produced half-maximal inhibition $\left(p I C_{50}=-\log \mathrm{IC}_{50}\right)$ and $n$ is the slope factor. The $95 \%$ confidence intervals for $\mathrm{pEC}_{50}$ and $\mathrm{pIC}_{50}$ were obtained as the product of the standard deviation times the appropriate value from the $t$ distribution. In the text, confidence limits (95\% CI) have been transformed to a linear scale. Except as noted, results are presented as mean \pm SEM. GYKI 53655 generously was provided by Eli Lilly and Company. Symphony Pharmaceuticals kindly supplied SYM 2081. All other compounds were from Research Biochemicals International (Natick, MA) or Sigma (St. Louis, MO).

\section{RESULTS}

\section{Inhibition of AMPA receptors by GYKI 53655}

AMPA receptors expressed by cultured hippocampal neurons mediate substantial whole-cell currents when activated by either kainate or glutamate. As previously described for both native
A
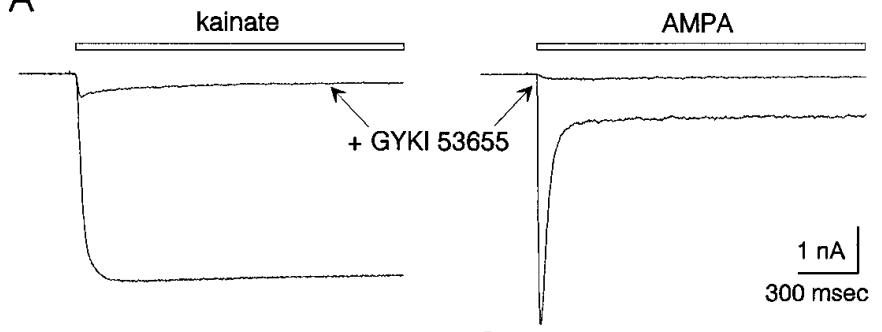

B

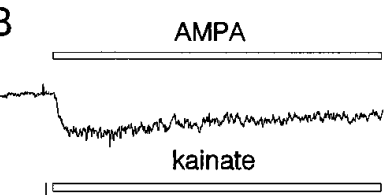

C

aspartate
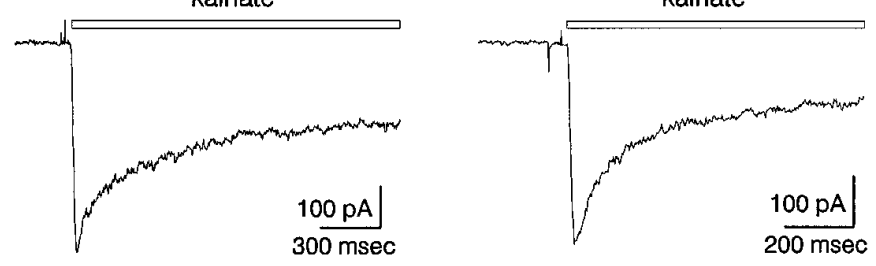

D

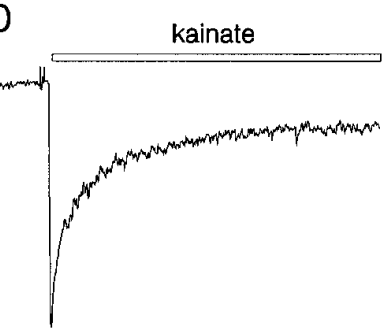

AMPA

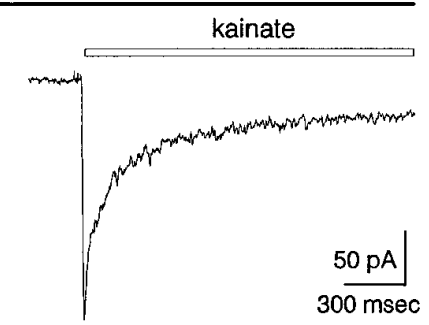

Figure 1. Currents mediated by AMPA and kainate receptors in cultured hippocampal neurons. $A$, Whole-cell currents evoked by 300 $\mu \mathrm{M}$ kainate (left) and $1 \mathrm{mM}$ AMPA (right) in the absence or (superimposed) presence of $100 \mu \mathrm{M}$ GYKI 53655. All four traces are from the same cell. Currents in the presence of GYKI are shown on an expanded scale in $B$. GYKI was added to both the vehicle and the agonistcontaining solutions. $C$, In a different cell, current recorded during application of $500 \mu \mathrm{M}$ aspartate (top) or $300 \mu \mathrm{M}$ kainate (bottom), both in the continuous presence of $100 \mu \mathrm{M}$ GYKI 53655 and $2 \mu \mathrm{M}$ MK-801. $D$, Currents elicited by $300 \mu \mathrm{M}$ kainate with $100 \mu \mathrm{M}$ GYKI in the absence (left) or presence (right) of $5 \mu \mathrm{M}$ AMPA.

(Kiskin et al., 1986; Patneau and Mayer, 1991) and recombinant (Sommer et al., 1990) AMPA receptors, the whole-cell currents evoked by kainate displayed very little desensitization, whereas currents elicited by glutamate or AMPA decayed significantly over a time course of $20-50 \mathrm{msec}$ (Figs. $1 A, 2 C$ ). To determine whether hippocampal neurons express functional kainatepreferring receptors, we applied kainate, glutamate, and AMPA together with the noncompetitive AMPA receptor antagonist GYKI 53655. Previous work on native AMPA receptors expressed by cortical (Wilding and Huettner, 1995) and hippocampal (Donevan et al., 1994; Paternain et al., 1995) neurons has shown that GYKI 53655 produces virtually complete block of AMPA receptors, with an $\mathrm{IC}_{50}$ of $\sim 1 \mu \mathrm{M}$. For all of our experiments, GYKI 53655 was used at $100 \mu \mathrm{M}$ to ensure $>99 \%$ inhibition of AMPA receptors. Figure $1 A, B$ shows the whole-cell currents evoked by rapid applications of kainate and AMPA in the continuous presence or absence of GYKI 53655. For the cell shown in Figure $1 A, B$, the peak current evoked by kainate in the presence of GYKI 53655 was $13 \%$ of the current evoked in control solution without the AMPA antagonist. In eight cells tested with and 
without $100 \mu \mathrm{M}$ GYKI 53655, kainate plus GYKI evoked, on average, $15 \pm 3 \%$ of the peak current elicited by kainate alone.

Our first priority in evaluating the current that remained in the presence of GYKI 53655 was to determine whether or not it was mediated by kainate receptors. In particular, we were concerned that all of the various AMPA receptor subunit combinations might not be equally sensitive to inhibition by GYKI 53655 (Johansen et al., 1995; Partin and Mayer, 1996). Several lines of evidence, however, indicate that AMPA receptors contribute very little to the residual current. As shown in Figure $1 D$, steady-state application of $5 \mu \mathrm{M}$ AMPA, which is sufficient to elicit $50 \%$ of maximal activation at AMPA receptors (Wong et al., 1994; Woodward et al., 1995), produced little or no inward current and, more importantly, caused very little change in the whole-cell current evoked by kainate. In recordings from six cells, the peak current evoked by $300 \mu \mathrm{M}$ kainate in the presence of $5 \mu \mathrm{M}$ AMPA was $98 \pm 3 \%$ of that recorded in control solution. At much higher concentrations (0.5-1 mM), AMPA alone evoked a small and slowly desensitizing current in the presence of GYKI 53655 (Fig. 1A,B).

\section{Differential inhibition of AMPA and kainate receptors by lanthanum and SYM 2081}

In addition to the selective antagonism of AMPA receptors by 2,3-benzodiazepines (Paternain et al., 1995; Wilding and Huettner, 1995), kainate- and AMPA-preferring receptors also show differential sensitivity to inhibition by lanthanum (Huettner, 1991) and by SYM 2081, which is the $2 S, 4 R$ diastereomer of 4-methylglutamate (Jones et al., 1997; Zhou et al., 1997). As shown in Figure $2 A, C$, activation of AMPA receptors by kainate or glutamate in the absence of GYKI 53655 was potentiated by lanthanum $(15 \mu \mathrm{M})$, as previously described by Reichling and MacDermott (1991). In contrast, the currents evoked by kainate or glutamate in the presence of GYKI 53655 were strongly inhibited by $15 \mu \mathrm{M}$ lanthanum (Fig. $2 B, D$ ). Blockade of kainate receptor currents was half-maximal at $2 \mu \mathrm{M}$ lanthanum $(n=5)$, whereas a much higher concentration was required to suppress the currents via AMPA receptors $\left(\mathrm{IC}_{50}>100 \mu \mathrm{M}\right.$; see Reichling and MacDermott, 1991).

As shown in Figure 2E, whole-cell currents mediated by AMPA receptors were nearly unaffected by low concentrations of SYM 2081. In the absence of GYKI 53655, $1 \mu \mathrm{M}$ SYM 2081 blocked $4 \pm$ $2 \%$ of the current evoked at steady state $(n=5)$. By contrast, continuous application of $1 \mu \mathrm{M}$ SYM 2081 in the presence of GYKI 53655 produced much greater inhibition of peak kainate current (Fig. $2 F ; 88 \pm 3 \%$ inhibition, $n=6$ ). At higher concentrations, SYM 2081 evoked desensitizing currents in the presence of GYKI 53655 (Figs. 3, 4), with an $\mathrm{EC}_{50}$ of $\sim 50 \mu \mathrm{M}$.

\section{The residual current is not mediated by electrogenic uptake}

In addition to gating ion channels, certain excitatory amino acids also can elicit membrane currents by serving as substrates for electrogenic carrier proteins. Although classical uptake mechanisms display strongly rectifying current-voltage relations that do not reverse polarity (Cull-Candy et al., 1988), more recent work (Arriza et al., 1994; Wadiche et al., 1995) on cloned glutamate transporters has revealed several electrogenic isoforms that support both inward and outward currents during applications of transported substrates. At least one of these cloned transport proteins has been shown to bind kainate with micromolar affinity, but unlike transported substrates, kainate was not able to elicit
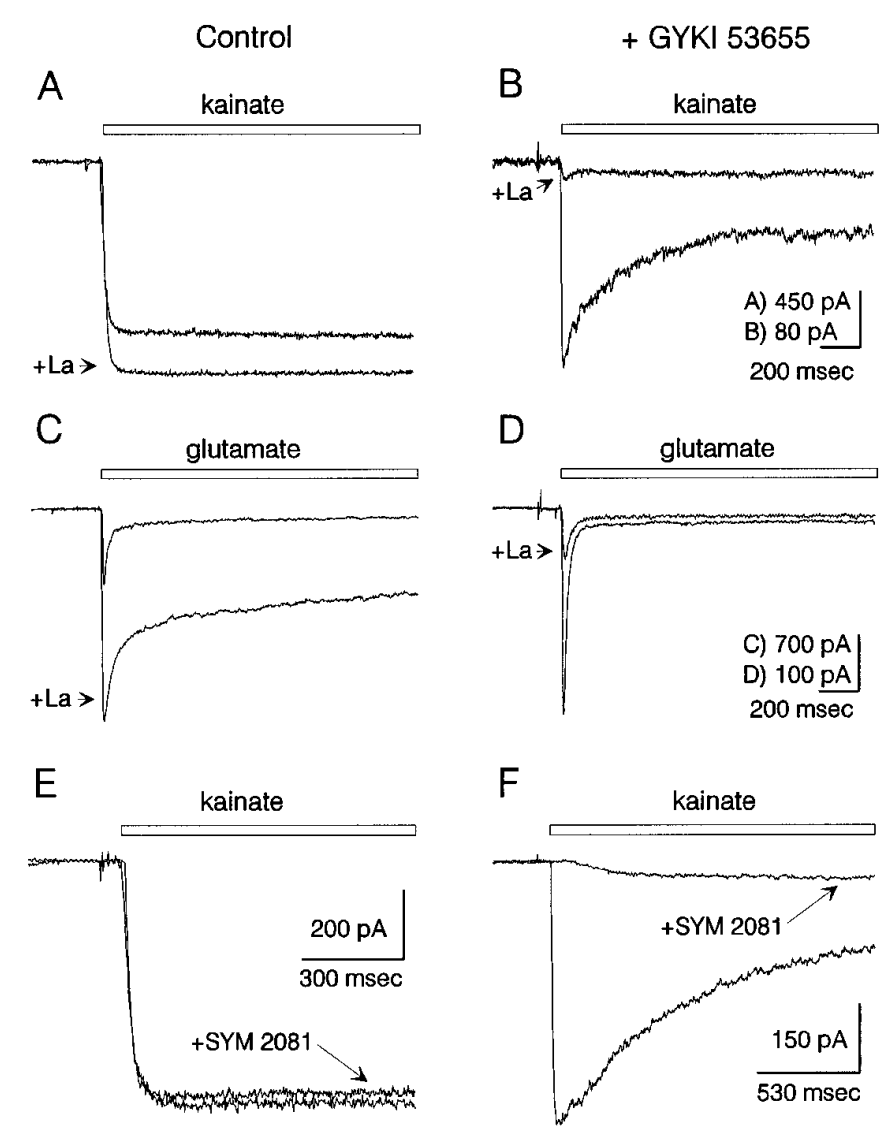

Figure 2. Differential inhibition of AMPA and kainate receptors by lanthanum and SYM 2081. Currents evoked by $100 \mu \mathrm{M}$ kainate $(A)$ and $500 \mu \mathrm{M}$ glutamate $(C)$ in the absence of GYKI 53655 were potentiated by coapplication of $15 \mu \mathrm{M}$ lanthanum. In the presence of $100 \mu \mathrm{M}$ GYKI 53655 , currents elicited by $300 \mu \mathrm{M}$ kainate $(B)$ and $1 \mathrm{~mm}$ glutamate $(D)$ were strongly inhibited by $15 \mu \mathrm{M}$ lanthanum. Traces in $A-D$ are from four different cells. SYM $2081(1 \mu \mathrm{M})$ had little effect on current elicited by $100 \mu \mathrm{M}$ kainate in the absence of GYKI $53655(E)$ but in a different cell caused strong inhibition of current evoked by $300 \mu \mathrm{M}$ kainate in the presence of GYKI $53655(F)$. Lanthanum and SYM 2081 were added both to the control and to the agonist-containing solutions. Holding potential, $-90 \mathrm{mV}$.

currents (Arriza et al., 1994; Wadiche et al., 1995). To determine whether the currents elicited by kainate in the presence of GYKI 53655 might involve a novel transport mechanism, we compared the current evoked by kainate with that elicited by L-aspartate. Because all of the known transport proteins show little selectivity between glutamate and aspartate (Arriza et al., 1994), we reasoned that aspartate should elicit a substantial current if a carrier were involved. As shown in Figure $1 C$, L-aspartate (in the presence of $10 \mu \mathrm{M}$ MK-801) elicited little or no current when applied to cells that displayed a substantial response to kainate. In five cells tested with rapid applications of both compounds, aspartate evoked only $7 \pm 3 \%$ of the current elicited by kainate. Furthermore, the currents elicited by kainate were unaffected by coapplication of aspartate $\left(I / I_{\text {control }}=97 \pm 6 \%, n=5\right)$.

\section{Current-voltage relations}

Figure 3 shows the current-voltage relations for whole-cell current activated by kainate, glutamate, and SYM 2081 in the presence of GYKI 53655. Peak current was determined at a series of different holding potentials from -90 to $+30 \mathrm{mV}$ and plotted as a function of potential. In most of the cells tested with kainate 
A
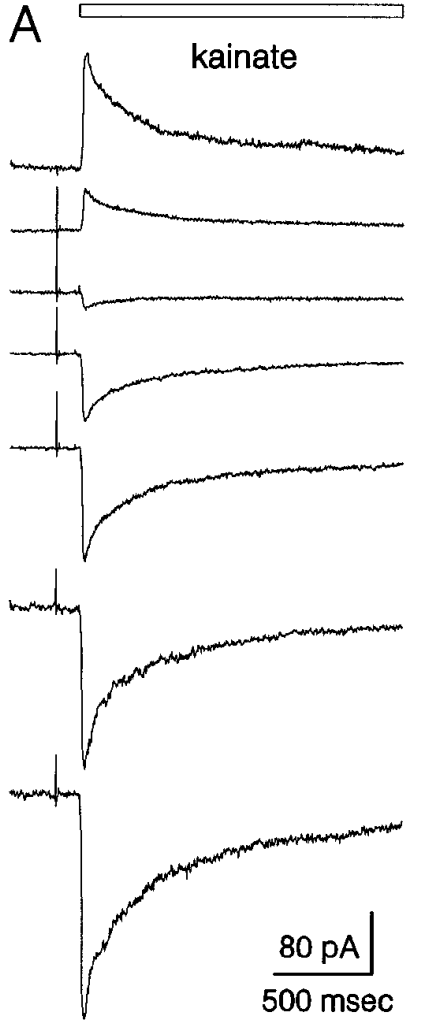

B

Figure 3. Current-voltage relations for $300 \mu \mathrm{M}$ kainate, $1 \mathrm{mM}$ glutamate, and $500 \mu \mathrm{M}$ SYM 2081. A, Whole-cell currents evoked in the continuous presence of $100 \mu \mathrm{M}$ GYKI 53655 at holding potentials of (from top to bottom) +30 , $+10,-10,-30,-50,-70$, and -90 . For clarity, the traces have been displaced relative to zero current. $B$, Plots of normalized peak currents that have been scaled by the mean current for 14 cells (kainate) and five cells each ( $\mathrm{glu}$ tamate and SYM 2081).

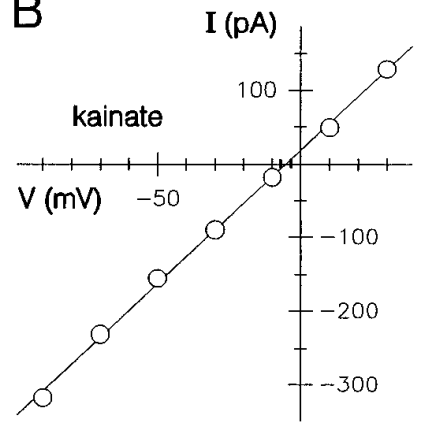

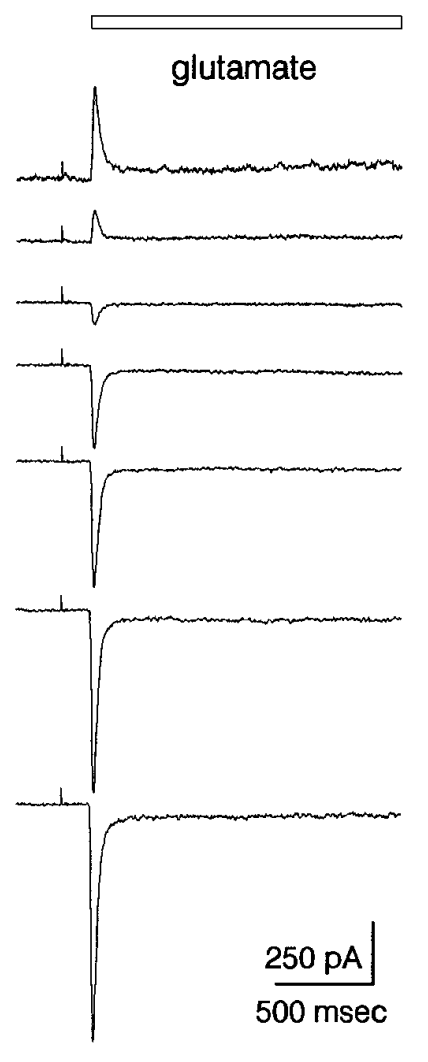
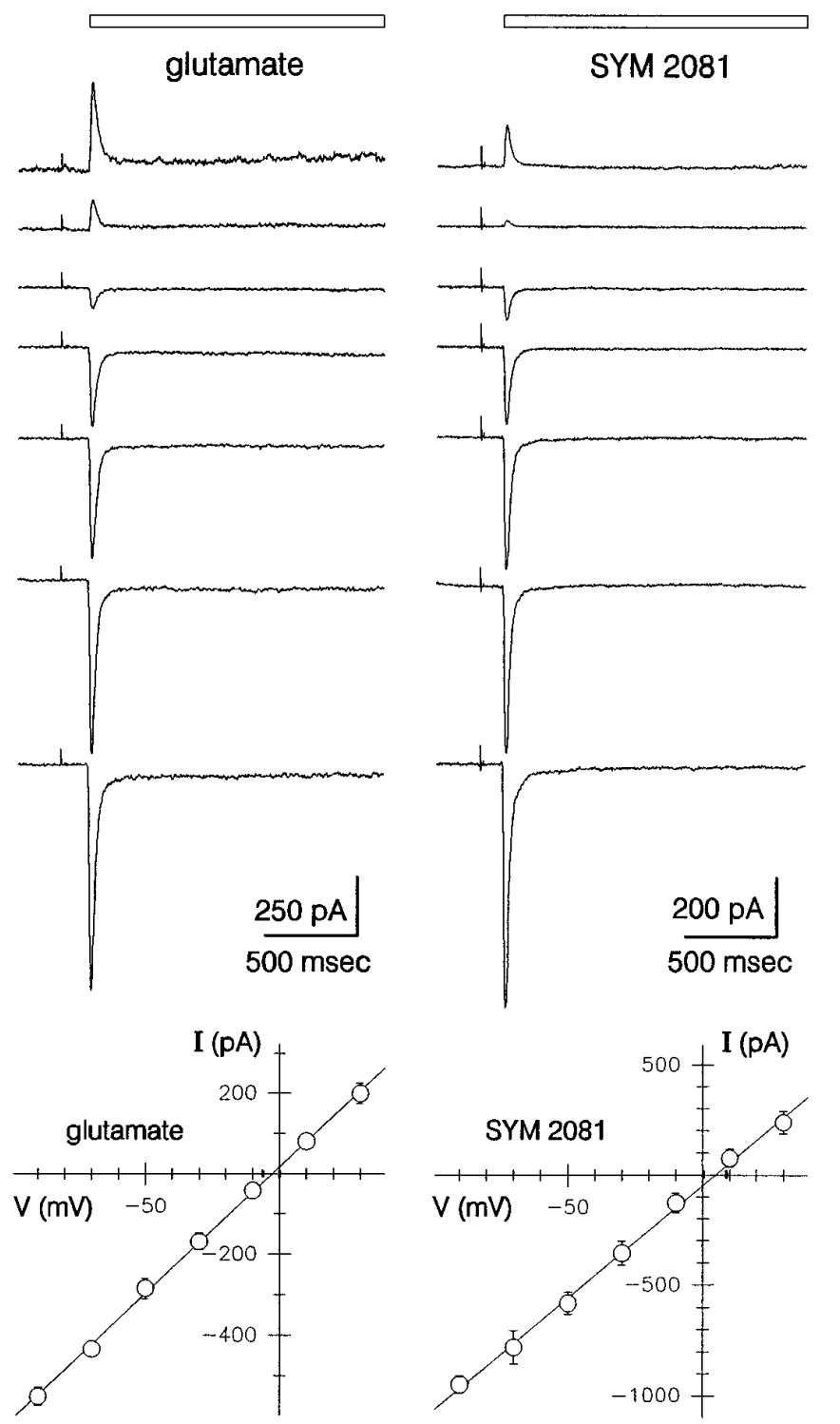

( $n=18$ of 23), glutamate $(n=7$ of 8$)$, or SYM $2081(n=5$ of 5$)$, the $I-V$ relations were relatively linear, and the currents reversed polarity between -10 and $+10 \mathrm{mV}$. In a few cells ( 6 of 36) the peak current displayed inward rectification (data not shown). Analysis of data from cells with linear $I-V$ relations yielded reversal potentials of $-5.2 \pm 1.2 \mathrm{mV}(n=14)$ for kainate, $-2.8 \pm$ $3.1 \mathrm{mV}(n=7)$ for glutamate, and $+4.6 \pm 4.2 \mathrm{mV}(n=5)$ for SYM 2081. Differences among the means were not significant $(p<0.05)$, as determined by one way ANOVA and StudentNewman-Keuls test.

\section{Time course of desensitization and recovery}

The onset of desensitization to kainate showed considerable variability from one cell to the next. In most cells the decay of current during a continuous application of kainate was poorly fit by a single exponential function but was well described by a sum of two exponentials plus a steady-state component that ranged between 10 and $>60 \%$ of the initial peak current (Table 1). Many of the cells displayed a rapid component of desensitization with a time constant of $\sim 30 \mathrm{msec}$, whereas all of the cells had a slower component of decay with $\tau$ in the range of
300-600 msec (Table 1). In contrast to kainate, the currents elicited by glutamate and SYM 2081 displayed much lower steady-state currents relative to their peak amplitudes.

The recovery of peak current amplitude after a $2 \mathrm{sec}$ agonist pulse was monitored for glutamate, kainate, and SYM 2081 (Fig. 4). For all three agonists the recovery of peak current was best described by two exponentials. Recovery was significantly more rapid for kainate and glutamate than for SYM 2081. Even for glutamate and kainate, however, the recovery of currents mediated by kainate receptors was much slower than previous studies had observed for AMPA receptors (Patneau and Mayer, 1991).

\section{Concentration-response relations}

The plots in Figure 5 show the concentration dependence of receptor activation by kainate and glutamate. Activation of current was detected first at concentrations near $0.5 \mu \mathrm{M}$ kainate or 10 $\mu \mathrm{M}$ glutamate. Peak current was half-maximal at $23 \mu \mathrm{M}$ for kainate and $310 \mu \mathrm{M}$ for glutamate. The steady-state current elicited by kainate was half-maximal at $7 \mu \mathrm{M}$.

As shown in Figures 2-5, exposure to glutamate or SYM 2081 produced virtually complete desensitization. To determine the con- 


\begin{tabular}{|c|c|c|c|c|c|c|c|}
\hline Agonist & $\begin{array}{l}\text { Peak I } \\
\text { pA }\end{array}$ & $\begin{array}{l}\text { Steady } \\
{\text { state },{ }^{a}(\%)}(\%)\end{array}$ & $\begin{array}{l}\tau 1^{b} \\
\operatorname{msec}\end{array}$ & $\begin{array}{l}\operatorname{Amp} 1^{c} \\
(\%)\end{array}$ & $\begin{array}{l}\tau 2^{b} \\
\mathrm{msec}\end{array}$ & $\begin{array}{l}\operatorname{Amp} 2^{c} \\
(\%)\end{array}$ & $n$ \\
\hline Kainate $(300 \mu \mathrm{M})$ & $-649 \pm 42$ & $27 \pm 2$ & $27 \pm 3$ & $78 \pm 3$ & $405 \pm 31$ & $22 \pm 3$ & 21 \\
\hline Glutamate (1 mM) & $-831 \pm 142$ & $8 \pm 1$ & $38 \pm 4$ & $96 \pm 1$ & $393 \pm 67$ & $4 \pm 1$ & 15 \\
\hline SYM $2081(500 \mu \mathrm{M})$ & $-698 \pm 102$ & $6 \pm 2$ & $28 \pm 3$ & $98 \pm 1$ & $391 \pm 99$ & $2 \pm 1$ & 14 \\
\hline
\end{tabular}

All values are mean \pm SEM. The holding potential was $-90 \mathrm{mV}$.

${ }^{a}$ Steady-state current at the end of a $2 \mathrm{sec}$ application as a percentage of the initial peak.

${ }^{b}$ Time constants for the best fit of two exponentials to the decaying component of current.

${ }^{c}$ Fractional amplitude of each exponential component as a percentage of the total decay.

centration dependence of steady-state desensitization, we applied the agonists for $10 \mathrm{sec}$, and they were followed immediately by a test application of a near-saturating agonist dose. Inhibition of the peak current elicited by the test application was half-maximal at $13 \mu \mathrm{M}$ for glutamate and $0.22 \mu \mathrm{M}$ for SYM 2081 (Fig. 6).

\section{Action of Concanavalin A}

Incubation with lectins, including Concanavalin A (Con A), has been shown to eliminate desensitization of native kainate receptors in dorsal root ganglion neurons (Huettner, 1990; Wong and Mayer, 1993) as well as recombinant kainate receptors expressed in Xenopus oocytes (Egebjerg et al., 1991) or HEK 293 cells (Partin et al., 1993). In these earlier studies, the currents elicited by kainate showed very little desensitization after exposure to Con A and were typically 1.5- to twofold larger than the peak currents elicited before lectin treatment. By contrast, exposure of hippocampal neurons to Con A invariably led to a decrease in the maximum current amplitude (Fig. 7). In individual cells tested before and after exposure to Con A, peak current amplitude after treatment with the lectin was $45 \pm 6 \%$ (kainate, $n=6$ ) and $54 \pm$ $11 \%$ (glutamate, $n=5$ ) of that recorded before exposure.

After treatment with Con A, the currents evoked by kainate, glutamate, and SYM 2081 all showed a lower ratio of peak to steady-state current amplitude. With kainate as the agonist, the absolute level of steady-state current was the same as or slightly larger than before exposure to the lectin, whereas for glutamate and SYM 2081 the increase in steady-state current was more substantial (Fig. 7A). Current-voltage relations and sensitivity to lanthanum were unchanged in Con A-treated cells (data not shown). As shown in Figure 7, however, the concentration-response relations for kainate and glutamate were shifted slightly to the left after exposure to Con $\mathrm{A}$. The $\mathrm{EC}_{50}$ values for activation of whole-cell current were $7 \mu \mathrm{M}$ for kainate and $168 \mu \mathrm{M}$ for glutamate in cells that had been treated with Con A.

\section{DISCUSSION}

\section{Isolation of current mediated by kainate receptors}

Our recordings from cultured hippocampal neurons have demonstrated the selective activation of kainate receptors during continuous exposure to the noncompetitive AMPA receptor antagonist GYKI 53655. In previous studies, this drug was shown to exhibit >200-fold selectivity for native AMPA versus kainate receptor subtypes (Paternain et al., 1995; Wilding and Huettner, 1995). More recent work on GYKI compounds, however, revealed a lower potency of inhibition for currents recorded in cells expressing specific combinations of cloned AMPA receptor subunits (Johansen et al., 1995; Partin and Mayer, 1996). In addition, a voltage-dependent component of AMPA receptor blockade by GYKI 52466 has been observed in some neuronal cell popula- tions. Collectively, these studies raised the possibility that currents recorded from neurons in the presence of GYKI 53655 might be mediated by a subpopulation of AMPA receptors with lower sensitivity to the drug or with novel time- or use-dependent inhibition. Our results with chronic application of AMPA $(5 \mu \mathrm{M})$, lanthanum $(15 \mu \mathrm{M})$, or SYM $2081(1 \mu \mathrm{M})$ argue against this possibility and, instead, provide strong evidence that currents recorded in GYKI 53655 receive very little contribution from unblocked AMPA receptors.

In previous work, exposure to low micromolar concentrations of AMPA or glutamate has been shown to produce significant desensitization of AMPA-preferring receptors (Kiskin et al., 1986; Trussell and Fischbach, 1989; Patneau and Mayer, 1991). However, in the present study $5 \mu \mathrm{M}$ AMPA had little effect on either the rise time or amplitude of currents evoked by coapplication of kainate, which suggests that AMPA receptors do not underlie the currents recorded during continuous exposure to GYKI.

Our experiments with lanthanum confirmed the dual action of this ion at neuronal AMPA receptors, which was described previously by Reichling and MacDermott (1991). Currents mediated by AMPA receptors were blocked by lanthanum concentrations $>100 \mu \mathrm{M}$ (data not shown) but were potentiated by application of $15 \mu \mathrm{M}$ lanthanum. In contrast, $15 \mu \mathrm{M}$ lanthanum produced strong inhibition of currents recorded in the presence of GYKI 53655, a result that is consistent with previous evidence for blockade of both native (Huettner, 1991) and recombinant (E. Stack, T. Wilding, J. Huettner, unpublished observations) kainate receptors by micromolar lanthanum.

Finally, the glutamate analog SYM 2081, which recently was shown to produce potent desensitization of kainate receptors (Jones et al., 1997; Zhou et al., 1997), caused nearly complete blockade of currents recorded in the presence of GYKI 53655. In solutions that lacked GYKI, the small fraction of steady-state current inhibited by application of SYM 2081 was approximately the same amplitude as the kainate receptor-mediated currents that were recorded in the presence of GYKI. We did not attempt to demonstrate a lack of potentiation by the AMPA receptorselective modulator cyclothiazide (Wong and Mayer, 1993; Partin et al., 1993). Previous work has shown that cyclothiazide causes an allosteric reduction in the potency of GYKI inhibition at AMPA receptors (Johansen et al., 1995; Partin and Mayer, 1996; Yamada and Turetsky, 1996), which would have made experiments with cyclothiazide difficult to interpret.

\section{Physiological properties}

The currents we recorded in cells from postnatal animals displayed two major differences from earlier results obtained in embryonic hippocampal neurons (Lerma et al., 1993; Paternain et al., 1995; Ruano et al., 1995). In all of the cells that we studied, 
A

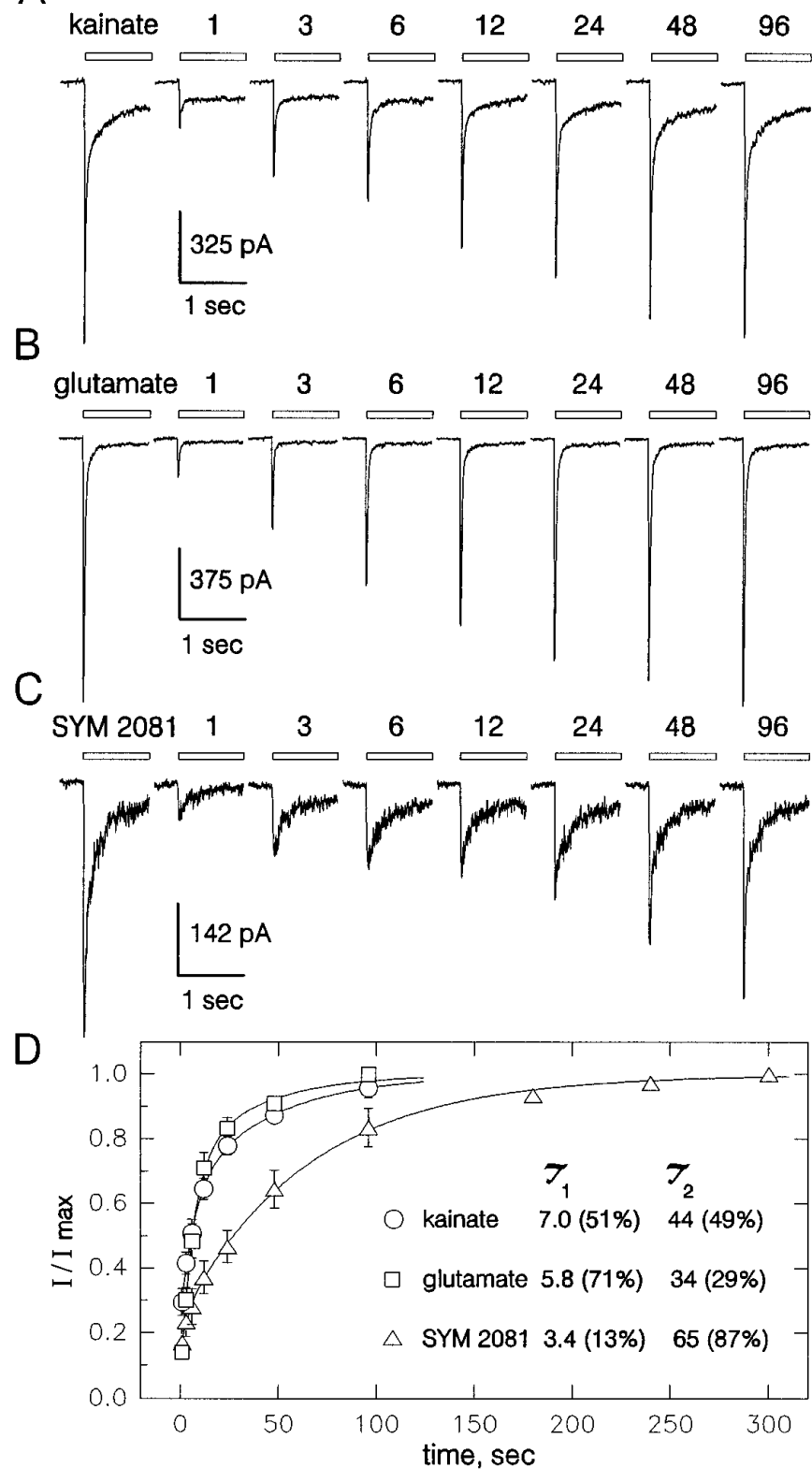

Figure 4. Recovery from desensitization. Whole-cell currents evoked by $300 \mu \mathrm{M}$ kainate $(A), 1 \mathrm{~mm}$ glutamate $(B)$, and $500 \mu \mathrm{M}$ SYM $2081(C)$ in the continuous presence of $100 \mu \mathrm{M}$ GYKI 53655. Each panel shows a control response to the agonist and currents evoked at recovery times of $1,3,6,12$, 24, 48, and $96 \mathrm{sec}$ after a $2 \mathrm{sec}$ agonist application. $D$, Peak current (mean \pm SEM) evoked by kainate $(O, 7$ cells), glutamate $(\square, 13$ cells), and SYM $2081(\triangle, 8$ cells) as a fraction of the control response plotted as a function of time. Time constants for the rapid $\left(\tau_{1}\right)$ and slow $\left(\tau_{2}\right)$ phase of recovery are provided in seconds (\% contribution by each phase is given in parentheses).

kainate evoked currents with a prominent slow phase of desensitization and a substantial maintained component of steady-state current. Furthermore, the current-voltage relation in most cells was relatively linear, with only a few cells displaying prominent inward rectification. In contrast, Lerma and colleagues (1993) found that desensitization to kainate was fast and complete in $>80 \%$ of the embryonic cells expressing kainate receptors. In addition, the currents mediated by these receptors had rectifying $I-V$ relations in nearly all cases (Ruano et al., 1995). Using
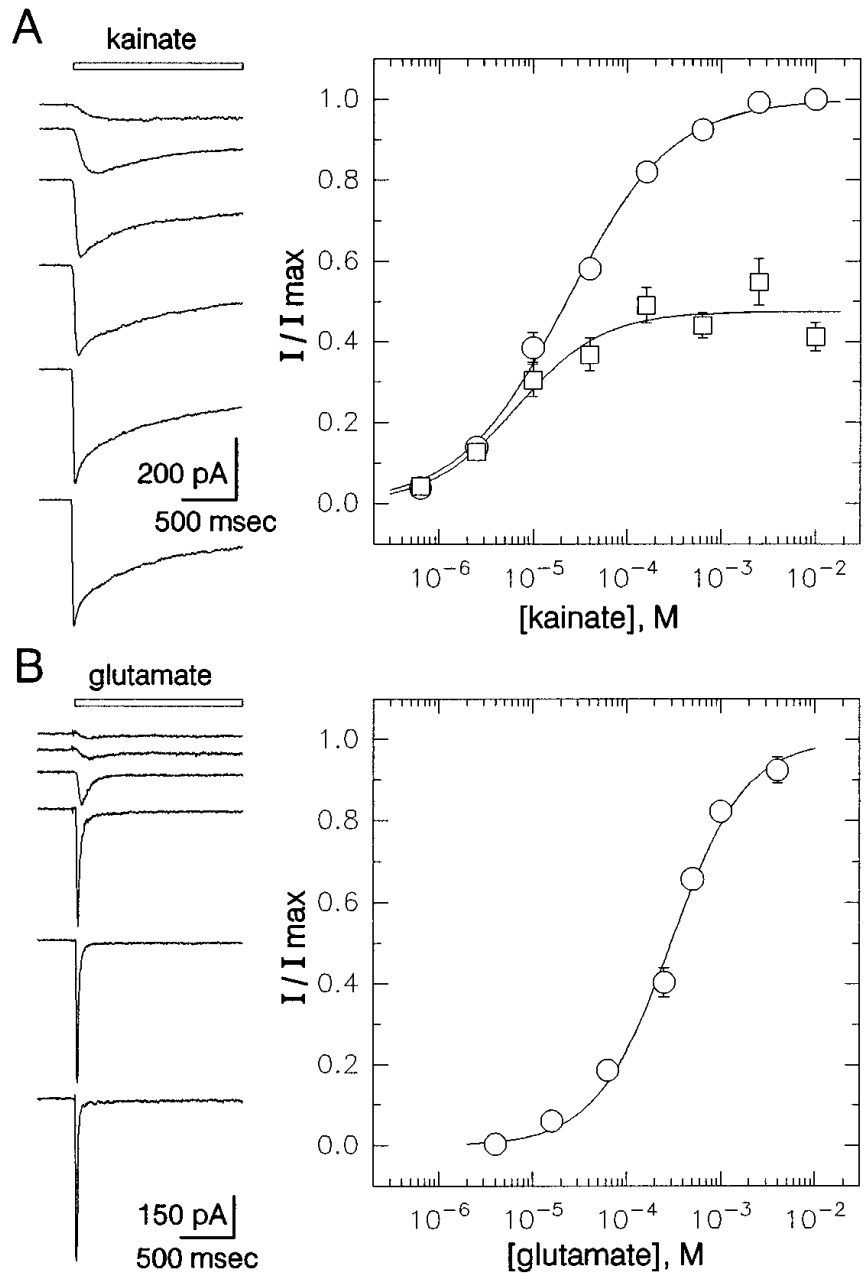

Figure 5. Concentration-response relations for receptor activation by kainate and glutamate in the presence of $100 \mu \mathrm{M}$ GYKI 53655. $A$, Currents evoked by $2.5,10,40,160$, and $630 \mu \mathrm{M}$ and $2.5 \mathrm{~mm}$ kainate. Peak $(\bigcirc)$ and steady-state $(\square)$ current as a fraction of the peak currents evoked by 2.5 or $10 \mathrm{~mm}$ kainate (mean \pm SEM) are plotted as a function of kainate concentration. Data from 7 to 20 cells contributed to each point. Smooth curves show the best fits of the logistic equation (see Materials and Methods). For peak current (O), $\mathrm{EC}_{50}=23 \mu \mathrm{M}(95 \% \mathrm{CI}, 19-27 \mu \mathrm{M}), n=$ $0.8 \pm 0.1$. At steady-state ( $\square), \mathrm{EC}_{50}=7 \mu \mathrm{M}(95 \% \mathrm{CI}, 4-12 \mu \mathrm{M}), n=0.9 \pm$ 0.2 . $B$, Currents elicited by $16,63,250$, and $500 \mu \mathrm{M}$ and 1 and $4 \mathrm{~mm}$ glutamate. Normalized peak current is plotted as a function of glutamate concentration; 6-19 cells were tested at each concentration. $\mathrm{EC}_{50}=310$ $\mu \mathrm{M}(95 \% \mathrm{CI}, 240-390 \mu \mathrm{M}), n=1.1 \pm 0.1$. Holding potential, $-90 \mathrm{mV}$.

RT-PCR to analyze the kainate receptor subunits expressed by individual embryonic neurons, Ruano et al. (1995) observed that in the majority of cells only mRNA for the GluR6 subunit was detected, although a few neurons contained mRNA for GluR5 as well as GluR6. This result fits reasonably well with the physiological profile of embryonic cells (Lerma et al., 1993), because previous work has shown that kainate produces faster, more complete desensitization of receptors composed of GluR6 subunits than for GluR5 (Herb et al., 1992; Sommer et al., 1992). In contrast, the desensitization properties, as well as the currents activated by high concentrations of AMPA (Fig. $1 A, B$ ), that we observed in postnatal neurons are inconsistent with the properties of homomeric GluR6 receptors (Herb et al., 1992; Sakimura et al., 1992; Sommer et al., 1992). Indeed, it is tempting to speculate that the kainate currents in neurons from postnatal animals reflect the 


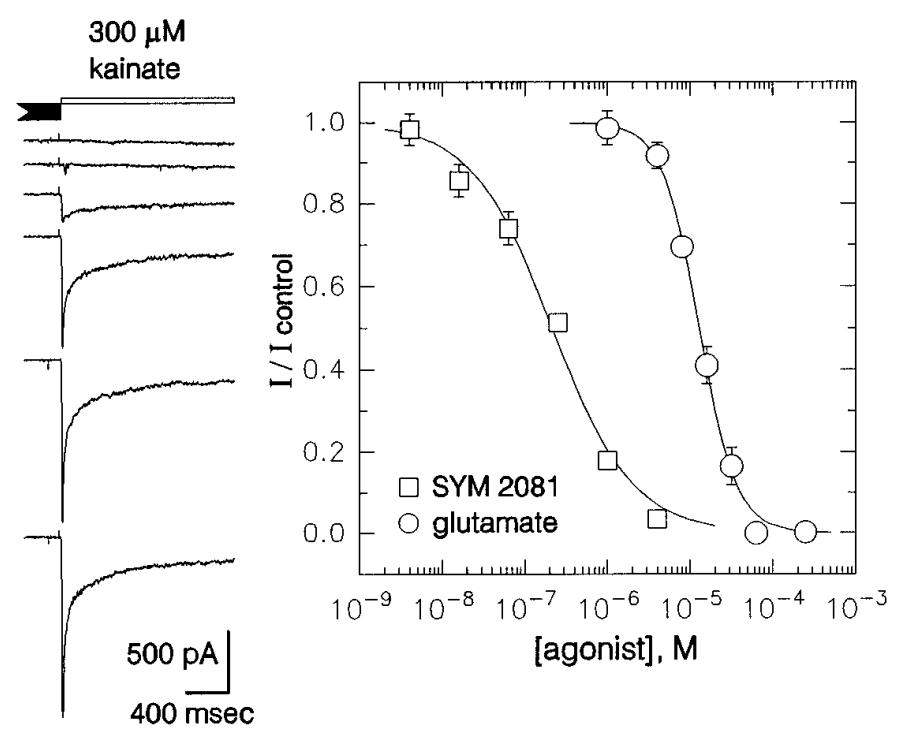

Figure 6. Concentration-response relations for steady-state desensitization by glutamate and SYM 2081. Traces show currents evoked by $300 \mu \mathrm{M}$ kainate after a $10 \mathrm{sec}$ exposure to (from top to bottom) 250,63,16,4,1, and $0 \mu \mathrm{M}$ glutamate (all in the presence of $100 \mu \mathrm{M}$ GYKI 53655). Holding potential, $-90 \mathrm{mV}$. Peak current (mean \pm SEM) elicited immediately after a $10 \mathrm{sec}$ agonist prepulse is plotted as a function of the prepulse concentration. The $\mathrm{IC}_{50}$ for SYM $2081(\square)$ was $0.22 \mu \mathrm{M}(95 \% \mathrm{CI}$, $0.19-0.27 \mu \mathrm{M}), n=0.9 \pm 0.1$. For glutamate $(\mathrm{O}), \mathrm{IC}_{50}=13 \mu \mathrm{M}(95 \% \mathrm{CI}$, $12-14 \mu \mathrm{M}), n=1.9 \pm 0.2$.

developmental increase in hippocampal GluR5 expression that has been described in vivo (Bahn et al., 1994). One argument against this hypothesis, however, is that Ruano et al. (1995) found virtually no correlation between GluR5 mRNA expression and desensitization kinetics in their sample of embryonic neurons.

The linear $I-V$ relations we observed suggest that postnatal neurons achieve relatively efficient editing at the $Q / R$ site (Sommer et al., 1991), which is known to govern channel permeation and rectification (Köhler et al., 1993). Previous studies have demonstrated a progressive increase in the extent of $\mathrm{Q}$ to $\mathrm{R}$ editing for both GluR5 and GluR6 during development in vivo (Bernard and Khrestchatisky, 1994). Analysis of editing at the Q/R site in embryonic neurons showed that unedited GluR6(Q) mRNA predominates (Ruano et al., 1995), which is consistent with the strong rectification observed in these cells (Lerma et al., 1993; Ruano et al., 1995).

In contrast to AMPA receptors, which display relatively rapid recovery from desensitization (Patneau and Mayer, 1991), currents mediated by kainate receptors invariably recover more slowly (Huettner, 1990; Wong et al., 1994). In the present study, the time course of recovery from desensitization and the potency of steady-state desensitization by glutamate were in fairly close agreement with earlier work on kainate receptors (Wong et al., 1994; Jones et al., 1997). Similarly, the much slower recovery from desensitization induced by SYM 2081, as well as the difference in the slopes of steady-state desensitization curves for SYM 2081 and glutamate, have been observed in previous studies of native and recombinant receptors (Jones et al., 1997; Zhou et al., 1997). In contrast, however, SYM 2081 was found to be significantly less potent for both activation $\left(\mathrm{EC}_{50} \sim 50 \mu \mathrm{M}\right)$ and desensitization $\left(\mathrm{IC}_{50}=220 \mathrm{nM}\right)$ in hippocampal neurons than in HEK cells expressing GluR6 (0.1-1 $\mu \mathrm{M}$ and $8 \mathrm{nM}$, respectively; Jones et al., 1997; Zhou et al., 1997) or in DRG cells (160 nM and $11 \mathrm{~nm}$,
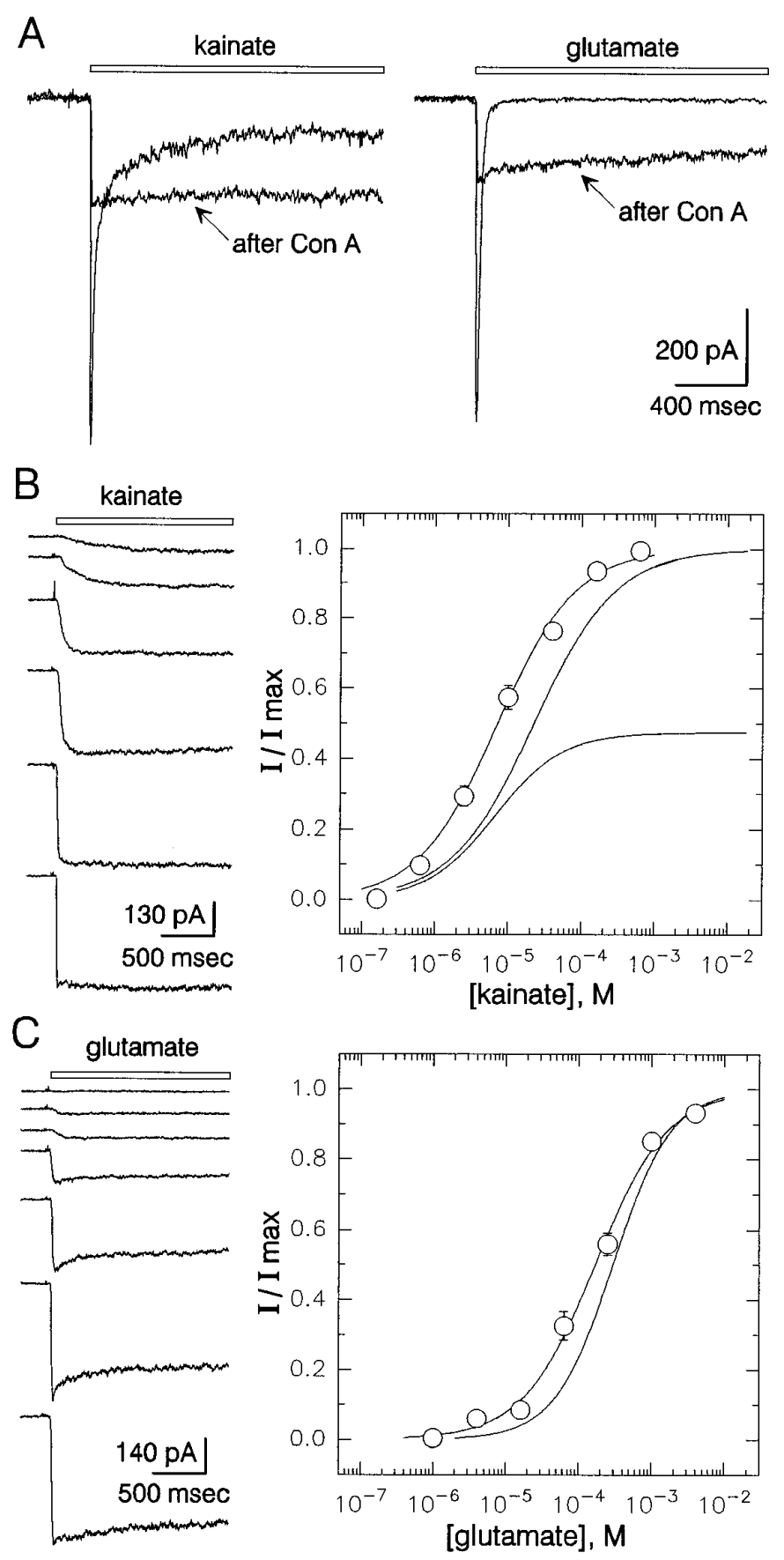

Figure 7. Action of Con A on hippocampal kainate receptors. A, Currents evoked by $300 \mu \mathrm{M}$ kainate before and after exposure to Con A are shown superimposed (left); also shown are currents evoked in a different cell by $1 \mathrm{~mm}$ glutamate (right). $B$, Currents evoked by $0.63,2.5,10,40,160$, and $630 \mu \mathrm{M}$ kainate in a cell exposed to Con A. Normalized current in 12-16 cells that had been exposed to Con $\mathrm{A}$ is plotted as a function of kainate concentration. $\mathrm{EC}_{50}=7 \mu \mathrm{M}(95 \% \mathrm{CI}, 6-8 \mu \mathrm{M}), n=0.8 \pm 0.1$. Smooth curves for peak and steady-state kainate current from Figure 5 are shown for comparison. $C$, Currents elicited by $1,4,16,63$, and $250 \mu \mathrm{M}$ and 1 and $4 \mathrm{~mm}$ glutamate in a cell exposed to Con A. Normalized peak current is plotted as a function of glutamate concentration; 5-17 cells were tested at each concentration. $\mathrm{EC}_{50}=168 \mu \mathrm{M}(95 \% \mathrm{CI}, 129-218 \mu \mathrm{M}), n=$ $0.9 \pm 0.1$. The smooth curve for peak current before Con A exposure from Figure 5 is shown for comparison. All traces were recorded in the continuous presence of $100 \mu \mathrm{M}$ GYKI. 
respectively; Jones et al., 1997). Further work will be needed to understand the structural and mechanistic bases of these differences.

Our $\mathrm{EC}_{50}$ values for activation of peak current by kainate (23 $\mu \mathrm{M})$ and glutamate $(310 \mu \mathrm{M})$ were relatively consistent with previous work on native and recombinant kainate receptors. Kainate evoked half-maximal currents at $22 \mu \mathrm{M}$ in embryonic hippocampal neurons (Lerma et al., 1993), 6-15 $\mu \mathrm{M}$ in freshly isolated DRG neurons (Huettner, 1990; Wong et al., 1994), and 3-6 $\mu \mathrm{M}$ in a cultured glial cell line (Patneau et al., 1994). Studies of cloned receptor subunits indicate $\mathrm{EC}_{50}$ values for kainate of 1-2 $\mu \mathrm{M}$ for cells expressing GluR6 (Sommer et al., 1992; Jones et al., 1997) and $34 \mu \mathrm{M}$ for homomeric GluR5 receptors (Sommer et al., 1992). By comparison, neuronal AMPA receptors typically require $120-$ $160 \mu \mathrm{M}$ kainate for half-maximal activation (Huettner, 1990; Patneau and Mayer, 1991), although more potent action by kainate has been reported at homomeric recombinant AMPA receptors (EC ${ }_{50}$ values of 30-50 $\mu \mathrm{M}$; see Hollmann and Heinemann, 1994).

\section{Action of Con A}

Earlier studies have shown that exposure to lectins, including Con A, will block desensitization of both native (Huettner, 1990; Wong and Mayer, 1993) and recombinant kainate receptors (Egebjerg et al., 1991; Partin et al., 1993). In cases in which individual cells have been tested with agonists before and after treatment with Con A, the loss of desensitization usually was associated with an increase in the maximal current amplitude on the order of 1.5- to twofold (Huettner, 1990; Partin et al., 1993; Wong and Mayer, 1993) (but see Patneau et al., 1994). In cultured hippocampal neurons, by contrast, exposure to Con A caused substantial reduction of the maximal currents elicited by kainate, glutamate, or SYM 2081 and only modest increases in the steady-state currents evoked by kainate. The weak effect of Con A on hippocampal currents in the absence of GYKI previously was taken as evidence against expression of functional kainate receptors by these cells (Wong and Mayer, 1993). The results of the present study, however, suggest that the effect of Con A on steady-state currents will be relatively subtle in solutions lacking GYKI-even for cells in which kainate receptors contribute $10-15 \%$ of the total current mediated by non-NMDA receptors.

Most studies of kainate receptors report little or no change in agonist $\mathrm{EC}_{50}$ values after exposure to Con A (Huettner, 1990; Wong et al., 1994), although in some cases a modest increase in potency has been observed (Jones et al., 1997). In the present study, the $\mathrm{EC}_{50}$ values for kainate and glutamate were slightly lower (i.e., higher potency) after treatment with Con A. This shift in $\mathrm{EC}_{50}$ values might represent a genuine change in apparent affinity, as can occur when AMPA receptor desensitization is blocked by cyclothiazide (Patneau et al., 1993); however, it also might reflect limitations in the rate of extracellular solution exchange during our whole-cell recordings. For example, previous experiments have shown that AMPA receptor kinetics are significantly faster in outside-out patches than in whole-cell recordings (Raman and Trussell, 1992; Patneau et al., 1993), yet it remains to be determined whether this difference is entirely owing to faster solution exchange or whether channel properties are modified during the process of patch excision (Margulis and Tang, 1996). Given these concerns, our $\mathrm{EC}_{50}$ values for peak current, as well as the time constants for the onset of desensitization, provide a basis for comparison with previous whole-cell experiments, but our results probably should be considered as upper limits for these values.

\section{Functional implications}

Although much circumstantial evidence for expression of kainate receptors in the CNS has been reported, until recently there was relatively little direct information concerning their functional properties. The results of the present study confirm the reports by Lerma and colleagues (Lerma et al., 1993; Paternain et al., 1995) that a majority of cultured hippocampal neurons express both kainate- and AMPA-preferring receptors. In our experiments on postnatal neurons virtually every cell displayed functional kainate receptors by $6-10 \mathrm{~d}$ in culture. Furthermore, as discussed above, the differences between our results and their work on embryonic cells are in broad agreement with known developmental changes in subunit expression and processing.

The role that these receptors play in hippocampal physiology and their precise relationship to high affinity kainate binding sites (London and Coyle, 1979), remain to be determined. Anatomical studies in rat and monkey hippocampus (Huntley et al., 1993; Petralia et al., 1994) suggest that kainate receptor subunits predominantly are localized to postsynaptic structures, although the existence of presynaptic receptors has not been ruled out. Early work in rat hippocampus demonstrated that low nanomolar doses of kainate, which should activate kainate receptors preferentially, elicit an increase in neuronal excitability (Robinson and Deadwyler, 1981; Westbrook and Lothman, 1983) and eventually produce selective neurotoxicity (Nadler et al., 1978). More recent efforts to detect a contribution by postsynaptic kainate receptors to excitatory synaptic transmission have gone unfulfilled, for the most part (Paternain et al., 1995; M. Finley and J. Huettner, unpublished observations); however, exposure of slices to nanomolar kainate has been shown to modulate the strength of evoked synaptic transmission (Chittajallu et al., 1996) by a mechanism that is likely to involve presynaptic kainate receptors. Additional work clearly is needed to establish the function of neuronal kainate receptors. Our results provide a better understanding of kainate receptor properties in postnatal neurons and therefore should aid in the design of further experiments to determine their role in synaptic physiology.

\section{REFERENCES}

Arriza JL, Fairman WA, Wadiche JI, Murdoch GH, Kavanaugh MP, Amara SG (1994) Functional comparison of three glutamate transporter subtypes cloned from human motor cortex. J Neurosci 14:5559-5569.

Bahn S, Volk B, Wisden W (1994) Kainate receptor gene expression in the developing rat brain. J Neurosci 14:5525-5547.

Bernard A, Khrestchatisky M (1994) Assessing the extent of RNA editing in the TMII regions of GluR5 and GluR6 kainate receptors during rat brain development. J Neurochem 62:2057-2060.

Bettler B, Boulter J, Hermans-Borgmeyer I, O'Shea-Greenfield A, Deneris E, Moll C, Borgmeyer U, Hollmann M, Heinemann S (1990) Cloning of a novel glutamate receptor subunit, GluR5: expression in the nervous system during development. Neuron 5:583-595.

Bettler B, Egebjerg J, Sharma G, Pecht G, Hermans-Borgmeyer I, Moll C, Stevens CF, Heinemann S (1992) Cloning of a putative glutamate receptor: a low affinity kainate-binding subunit. Neuron 8:257-265.

Boulter J, Hollmann M, O'Shea-Greenfield A, Hartley M, Deneris E, Maron C, Heinemann S (1990) Molecular cloning and functional expression of glutamate receptor subunit genes. Science 249:1033-1037.

Chittajallu R, Vignes M, Dev KK, Barnes JM, Colligridge GL, Henley JM (1996) Regulation of glutamate release by presynaptic kainate receptors in the hippocampus. Nature 379:78-81.

Cull-Candy SG, Howe JR, Ogden DC (1988) Noise and single channels activated by excitatory amino acids in rat cerebellar granule neurones. J Physiol (Lond) 400:189-222.

De Lean A, Munson PJ, Rodbard D (1978) Simultaneous analysis of 
families of sigmoidal curves: application to bioassay, radioligand assay, and physiological dose-response curves. Am J Physiol 235:E97-E102.

Donevan SD, Yamaguchi S, Rogawski MA (1994) Non- $N$-methyl-Daspartate receptor antagonism by 3-N-substituted 2,3-benzodiazepines: relationship to anticonvulsant activity. J Pharmacol Exp Ther 271:25-29.

Egebjerg J, Bettler B, Hermans-Borgmeyer I, Heinemann S (1991) Cloning of a cDNA for a glutamate receptor subunit activated by kainate but not AMPA. Nature 351:745-748.

Hancock AA, Bush EN, Stanisic D, Kyncl JJ, Lin CT (1988) Data normalization before statistical analysis: keeping the horse before the cart. Trends Pharmacol Sci 9:29-32.

Herb A, Burnashev N, Werner P, Sakmann B, Wisden W, Seeburg PH (1992) The KA-2 subunit of excitatory amino acid receptors shows widespread expression in brain and forms ion channels with distantly related subunits. Neuron 8:775-785.

Hollmann M, Heinemann S (1994) Cloned glutamate receptors. Annu Rev Neurosci 17:31-108.

Huettner JE (1990) Glutamate receptor channels in rat DRG neurons: activation by kainate and quisqualate and blockade of desensitization by Con A. Neuron 5:255-266.

Huettner JE (1991) Glutamate receptor channels in rat DRG neurons: selective inhibition by lanthanum and gadolinium. Soc Neurosci Abstr 17:1167.

Huntley GW, Rogers SW, Moran T, Janssen W, Archin N, Vickers JC, Cauley K, Heinemann SF, Morrison JH (1993) Selective distribution of kainate receptor subunits immunoreactivity in monkey neocortex revealed by a monoclonal antibody that recognizes glutamate receptor subunits GluR5/6/7. J Neurosci 13:2965-2981.

Johansen TH, Chaudhary A, Verdoorn TA (1995) Interaction among GYKI-52466, cyclothiazide, and aniracetam at recombinant AMPA and kainate receptors. Mol Pharmacol 48:946-955.

Jones KA, Wilding TJ, Huettner JE, Costa A-M (1997) Desensitization of kainate receptors by kainate, glutamate, and diastereomers of 4-methylglutamate. Neuropharmacology, in press.

Keinänen K, Wisden W, Sommer B, Werner P, Herb A, Verdoorn TA, Sakmann B, Seeburg PH (1990) A family of AMPA-selective glutamate receptors. Science 249:556-560.

Kiskin NI, Krishtal OA, Tsyndrenko AY (1986) Excitatory amino acid receptors in hippocampal neurons: kainate fails to desensitize them. Neurosci Lett 63:225-230.

Köhler M, Burnashev N, Sakmann B, Seeburg PH (1993) Determinants of $\mathrm{Ca}^{2+}$ permeability in both TM1 and TM2 of high affinity kainate receptor channels: diversity by RNA editing. Neuron 10:491-500.

Lerma J, Paternain AV, Naranjo JR, Mellström B (1993) Functional kainate-selective glutamate receptors in cultured hippocampal neurons. Proc Natl Acad Sci USA 90:11688-11692.

Lomeli H, Wisden W, Köhler M, Keinänen K, Sommer B, Seeburg PH (1992) High-affinity kainate and domoate receptors in rat brain. FEBS Lett 307:139-143.

London ED, Coyle JT (1979) Specific binding of $\left[{ }^{3} \mathrm{H}\right]$ kainic acid to receptor sites in rat brain. Mol Pharmacol 15:492-505.

Margulis M, Tang C-M (1996) The desensitization properties of nonNMDA GluR channels are altered by membrane excision. Soc Neurosci Abstr 22:337.

Nadler JV, Perry BW, Cotman CW (1978) Intraventricular kainic acid preferentially destroys hippocampal pyramidal cells. Nature 271:676-677.

Partin KM, Mayer ML (1996) Negative allosteric modulation of wildtype and mutant AMPA receptors by GYKI 53655. Mol Pharmacol 49:142-148.

Partin KM, Patneau DK, Winters CA, Mayer ML, Buonanno A (1993) Selective modulation of desensitization at AMPA versus kainate receptors by cyclothiazide and concanavalin A. Neuron 11:1069-1082.

Paternain AV, Morales M, Lerma J (1995) Selective antagonism of AMPA receptors unmasks kainate receptor-mediated responses in hippocampal neurons. Neuron 14:185-189.

Patneau DK, Mayer ML (1991) Kinetic analysis of interactions between kainate and AMPA: evidence for activation of a single receptor in mouse hippocampal neurons. Neuron 6:785-798.

Patneau DK, Vyklicky Jr L, Mayer ML (1993) Hippocampal neurons exhibit cyclothiazide-sensitive rapidly desensitizing responses to kainate. J Neurosci 13:3496-3509.
Patneau DK, Wright PW, Winters C, Mayer ML, Gallo V (1994) Glial cells of the oligodendrocyte lineage express both kainate- and AMPApreferring subtypes of glutamate receptor. Neuron 12:357-371.

Petralia RS, Wang Y-X, Wenthold RJ (1994) Histological and ultrastructural localization of the kainate receptor subunits, KA2 and GluR6/7, in the rat nervous system using selective antipeptide antibodies. J Comp Neurol 349:85-110.

Raman IM, Trussell LO (1992) The kinetics of the response to glutamate and kainate in neurons of the avian cochlear nucleus. Neuron 9:173-186.

Reichling DB, MacDermott AB (1991) Lanthanum actions on excitatory amino acid-gated currents and voltage-gated calcium currents in rat dorsal horn neurons. J Physiol (Lond) 441:199-218.

Robinson JH, Deadwyler SA (1981) Kainic acid produces depolarization of CA3 pyramidal cells in the in vitro hippocampal slice. Brain Res 221:117-127.

Ruano D, Lambolez B, Rossier J, Paternain AV, Lerma J (1995) Kainate receptor subunits expressed in single cultured hippocampal neurons: molecular and functional variants by RNA editing. Neuron 14:1009-1017.

Sakimura K, Morita T, Kushiya E, Mishina M (1992) Primary structure and expression of the $\gamma 2$ subunit of the glutamate receptor channel selective for kainate. Neuron 8:267-274.

Sommer B, Keinänen K, Verdoorn TA, Wisden W, Burnashev N, Herb A, Köhler M, Takagi T, Sakmann B, Seeburg PH (1990) Flip and flop: a cell-specific functional switch in glutamate-operated channels of the CNS. Science 249:1580-1585.

Sommer B, Köhler M, Sprengel R, Seeburg PH (1991) RNA editing in brain controls a determinant of ion flow in glutamate-gated channels. Cell 67:11-20.

Sommer B, Burnashev N, Verdoorn TA, Keinänen K, Sakmann B, Seeburg PH (1992) A glutamate receptor channel with high affinity for domoate and kainate. EMBO J 11:1651-1656.

Spruston N, Jonas P, Sakmann B (1995) Dendritic glutamate receptor channels in rat hippocampal CA3 and CA1 pyramidal neurons. J Physiol (Lond) 482:325-352.

Trussell LO, Fischbach GD (1989) Glutamate receptor desensitization and its role in synaptic transmission. Neuron 3:209-218.

Wadiche JI, Amara SG, Kavanaugh MP (1995) Ion fluxes associated with excitatory amino acid transport. Neuron 15:721-728.

Watkins JC, Evans RH (1981) Excitatory amino acid transmitters. Annu Rev Pharmacol Toxicol 21:165-204.

Westbrook GL, Lothman EW (1983) Cellular and synaptic basis of kainic acid-induced hippocampal epileptiform activity. Brain Res 273:97-109.

Wilding TJ, Huettner JE (1995) Differential antagonism of AMPApreferring and kainate-preferring receptors by 2,3-benzodiazepines. Mol Pharmacol 47:582-587.

Wilding TJ, Huettner JE (1996) Activation and desensitization of kainate receptors in cultured hippocampal neurons. Soc Neurosci Abstr 22:1540.

Wisden W, Seeburg PH (1993) A complex mosaic of high-affinity kainate receptors in rat brain. J Neurosci 13:3582-3598.

Wong LA, Mayer ML (1993) Differential modulation by cyclothiazide and concanavalin $\mathrm{A}$ of desensitization at native $\alpha$-amino-3-hydroxy-5methyl-4-isoxazolepropionic acid- and kainate-preferring glutamate receptors. Mol Pharmacol 44:504-510.

Wong LA, Mayer ML, Jane DE, Watkins JC (1994) Willardines differentiate agonist binding sites for kainate- versus AMPA-preferring glutamate receptors in DRG and hippocampal Neurons. J Neurosci 14:3881-3897.

Woodward RM, Huettner JE, Guastella J, Keana JFW, Weber E (1995) In vitro pharmacology of ACEA-1021 and ACEA-1031: centrally active quinoxalinediones with high affinity and selectivity for NMDA receptor glycine sites. Mol Pharmacol 47:568-581.

Yamada KA, Turetsky DM (1996) Allosteric interactions between cyclothiazide and AMPA/kainate receptor antagonists. Br J Pharmacol 117:1663-1672.

Zhou L-M, Gu Z-Q, Costa AM, Yamada KA, Mansson PE, Giordano T, Skolnick P, Jones KA (1997) $(2 S, 4 R)$-4-methylglutamic acid (SYM 2081): a potent, selective ligand for kainate receptors. J Pharmacol Exp Ther 280:422-427. 